\author{
Krystyna Rutkowska \\ Uniwersytet Wileński \\ Wilno
}

\title{
O języku, dawnych czasach i obrzędach w okolicach Mejkszt na Litwie
}

W niniejszej publikacji przedstawione zostaną teksty, nagrane w lipcu $2000 \mathrm{r}$. podczas badań terenowych na obszarze smołwieńskim polszczyzny północnokresowej. Pochodzą one od informatorki ze wsi Mejkszty (lit. Meikštai). Wieś jest położona w rejonie ignalińskim (lit. Ignalinos rajonas), na granicy z Białorusią. Teren ten charakteryzuje się historycznie ukształtowaną wielojęzycznością, gdzie sąsiadują ze sobą wsie litewskie, polskie i wsie staroobrzędowców ${ }^{1}$. Częste są też kontakty miejscowych mieszkańców z rodziną lub znajomymi, mieszkającymi na Białorusi. Mieszkańcy tych miejscowości znają cztery języki: polski, litewski, rosyjski i gwarę białoruską. W zachowanych wsiach polskich kodem podstawowym pozostaje dotychczas polszczyzna, której używa się we wszystkich trzech pokoleniach jako języka domowego, natomiast w kontaktach zewnętrznych mogą być używane pozostałe odmiany językowe.

Badania miały na celu nie tylko odnotowanie języka tych miejscowości, ale też udokumentowanie bardzo zróżnicowanej warstwy kulturowej, dlatego też nagrywane były

1 Teren ten był niejednokrotnie opisywany przez badaczy. Jako pierwsza gwary smołwieńskie opisała H. Turska (1939/1982). Autorka nie omawia odrębnie cech językowych tego terenu, tylko podaje je łącznie z cechami występującymi na Wileńszczyźnie. Opis niektórych właściwości fonetycznych i morfonologicznych tego terenu zawierają artykuły N. Ananiewej (Ананьева, 1974, 1982, 1983). Najnowszy opis sytuacji socjolingwistycznej na Smołwieńszczyźnie zawarty jest w artykule H. Karaś (2001). Wpływy litewskie oraz wschodniosłowiańskie w tych gwarach opisała K. Rutkowska $(2004,2013)$. 
opowieści o obrzędach, zwyczajach, a także pieśni ludowe. W trakcie badań stosowano różnorodne kwestionariusze - językowe, socjolingwistyczne i etnolingwistyczne. Poniżej przedstawiony tekst składa się z opowiadań o charakterze historycznym i etnograficznym. W zapisie półfonetycznym zostały zachowane podstawowe cechy języka informatorki, który reprezentuje odmianę smołwieńską polszczyzny na Litwie.

Informatorka mieszka od dwudziestu lat w Mejksztach (lit. Meikštai). Urodziła się w Moskwie w 1917 r., gdzie na migracji zarobkowej przebywali jej rodzice. Rodzice pochodzili ze wsi Kowaliszki (lit. Kavoliškès), do której wrócili po kilku latach pobytu w Moskwie. Informatorka ukończyła cztery klasy szkoły podstawowej w języku polskim w pobliskiej wsi Undrełany (lit. Undrelènai), potem jeszcze trzy lata uczyła się w szkole zawodowej w Święcianach (lit. Švenčionys). Rodzice mieli tylko dwa hektary ziemi, dlatego wszyscy chodzili do pracy do dworu. W młodości częściej mówiła po polsku i litewsku, w czasach sowieckich nauczyła się rosyjskiego i teraz często używa tego języka. Swoją polszczyznę określa jako niepoprawną, podobną do białoruskiego. Twierdzi, że mieszkańcy wsi na co dzień używają trzech języków. Nabożeństwa niedzielne są odprawiane w kościele w Puszkach (lit. Puškos) w dwu językach - polskim i litewskim. W mowie informatorki występują silne wpływy białoruskie, w mniejszym stopniu rosyjskie, spotykane są też stare zapożyczenia z języka litewskiego.

\section{TEKST}

... I ot nie moży przyjechać, pogody nie ma, mokro chodzić spocerować z takim pacank'om. A tak rodziny tu nikogo nie mam. Moża gdzie jest rodzina moja, Pam Bóg jej wie, ki'edyści mego taty rodzonego brat w K'aunnasie mieszkał, z cało rodzino swojo, pośla tamtej wielkiej wojny, on do K'aunasa, papa moj byusszy w Moskwie, ja tam rodziła sie w Moskwie, ja moskwiczka. Ja rodziła sie w Moskwie, za to co papa pracował tam na zowodzie u Moskwie. Jego r'odzina to o Kowaliszki, niedaleko ad Mejkszt, r'odzina papy mego, liczy sie i moja tu. Ale kiedyś było, jeszcze to przed tamto wojno wielko, to każdy wyjeżdżał, gdzie kto mog i szukał roboty, starał sie na robota. Tak i moj papa, do Moskwy wyjechał i tam na zawodzie pracował... zawody te nisztożyli sie, przyjechał... a brat papy pajechał do Kowna, na swoju r'odzinu nie zachciał wrócić, pajechał do Kowna i aż u Kownie tam. A gdzie kto, ja jeszcze mała byłam, nie mogłam szukać rodziny, a kiedy już zarosłam, już nie było, przyjechaưszy była stryjeczna siostra z Kowna, ale przed tym co był potop w Kownie, dawno to było i ot pośla tego potopu zerwała sie nasza korespond'encyja i wszystka znajomość. Czy gdzie jest kto żywy, czy nikogo nie ma mojej rodziny, moj dziadzia liczy sie, taty rodzony brat i chrzesny ojciec moj, tak co on podwójny mnie znaczy krewny, ale czy jest gdzie żywe oni pośle tego potopu, czy nie, nic nicht nie wie. Nie tyko co ja, moja rodzina, ale i sońsiedzi z którymaż on żył w wiosca tutej, w Kowaliszkach, 
nikomu nigdzie nie pisał. Jeszcze tam jego, jak on wyjeżdżał do Kowna, to zostawił walizki swoje, tam ubranie jakaś i nic, nic. To ja za to taka samotna, że u mnie taka nieszczeńścia, że rodzina moja... Ja samotna ze swojej strony z rodziny, a rodzina i znów pogineła.

Kiedy rodzice wrócili z Moskwy?

A jak tam wojna była, to oni w wojnie i przyjechali na swoja rodzina, pamientać nie pamientam, kiedy ja już zaczeła pamientać, jak chodziła po kwiaty ư błotach czympuryna taka z’bierać, żółte takie, co na wierzch nalane kwiaty, znacie chyba, topiła sie u kałuży wielkaj tam takaj, to sońsiadka mnie wyratowała, o to tyko pamientam, to takie jeszcze lata, a tak nic.

\section{To w Kowaliszkach żyli rodzice?}

Tak, w Kowaliszkach. To od Mejszt para kilometry beńdzie, Truszkowka i tedy Kowaliszki. Tam teraz w Kowaliszkach tylko jeden dom, mieszka rodzina, Polaki, swoje tam, zostawszy sie syn, ma syna, córku. Syn żonaty już, a córka panienka. On mnie też rodzina liczy sie przypada, po tatu mego, jego ojciec, co teraz o żyji tutej, to wychodzi jakoś stryjeczny brat moj.

\section{$Z$ Kowaliszek daleko do szkoły było?}

Daleko, pani kochana, aż do Undrełan chodzili my do szkoły, to musi jakich było może trzy kilometry, cztery, może do pieńciu było, Pam Bóg ich wie. Szułany od Kowaliszak, a tu jeszcze za Szułanami Undrełany. Ja do szkoły poszła dziesieńćletnia, za to co daleko była chodzić, a ja była taka, ci'enieńka, w'ontleńka, to rodzice nie puszczali do szkoły rano, to ja dziesieńćletnia poszła do szkoły, konczyła cztery kłasy tej szkoły, tedy rok pobyła w domu, postompiła ú Świeńciany do szkoły, koleżanka tu z Trukan taka, ta huczyła sie w tej szkołe u Świeńcianach, u zawodowej, przyjeżdżała do nas aż na jeziora, tam blisko u Kawaliszkach, nu to ona przyjeżdżała kompać sie. Ja z jo poznajomiłam sie i on'a mnie poradziła szkoła ta zawodowa w Świeńcianach, i ot ja postompiła do tej szkoły zawodowaj i trzy laty w szkole zawodowej uczyła sie, ja siedem lat uczyła sie. To szkoła była taka, wie pani, jednym słowem, jo konczyư⿱szy co chcesz, możesz i tak sama żyć, co uczy sie pracować, możysz postompić wyżej gdzie chcesz uczyć sie. Ja wyżej nie zachciała pastompić, mnie przygłaszali, ale dokuczyła, nie zachciała sie, zamonż poszłam. Przyjechałam do rodziny, ot nie lubia mjasta, mnie wjoska pachnie, mnie podoba sie wszystka praca, wszystkie zapachy, kwjaty, łonki na wjosce, a miasto nie lubie. I ot wiencej nie poszła uczyć sie, a uczyła sie tam wszystkiego czego, krawiectwa, trocha szyłam, wjonzać, wyszywać, o, to wszystko nas uczyli, przedmioty szkolne wszystkie, geografia, historia i jenzyk polski, śpiewy i wszystko. Nu i tedy konczyła szkoła i dwadziesty pierszy rok majonc wyszła zamonż. Panienskie <nazwisko> Wanażanka. Nazwisko papy Wanaga, ale jak powiedzieć na dziewczynu, to już 
niepieknie brzmi, to mnie przerzucili te znaczy ga na żet, zrobili Wanażanka. Tak już trzeba było.

\section{Czy ta szkoła była polska, gdzie pani cztery klasy skończyła?}

Polska. Tu jeszcze Polska była, przed wojno. Zreszto, pani kochana, nie powiem, jak granicy litewskie i polskie byli, to już... Wiem, że tyko do Litwy nie możno było napisać listu, o co była bieda. Pomimo, że tata był w Litwie, w Kownie, a ja listu do niego nie miałam prawa pisać, a chrzesna mama moja miaszkała w Rydze, w Łatwiji $i$ ot ja do chrzesnej mamy pisała list, a tedy chrzesna mama przesyłała do chrzesnego ojca. A ja nie wiem, czemu Litwa taka była niedobra, że ona tak sama siebie trzymała twardo. Do Łatwiji wyjeżdżali i na robota tutej od nas z Polski, z Łotwiji można było, a z Litwy nie. Cienżki naród. Tylko sam siebie lubi. Prawda, prawda, Litwini niedobre ludzi. Mało jest życzliwych ludzi Litwinów, mało, oni tyko samy siebie lubio. Pani kochana, wilka zmienisz, jeżeli jego beńdziesz karmić w domu i chciałaby, żeby byłby on zamiast psa, nie zrobisz jego psem. Nie, wilk był i beńdzie wilkiem, i tu to samo. Nu i oj cienżko było tu jak przy sawietach my żyli, bywało, pójdziesz, pajedzisz u Dukszty do magazynów tam, nu to ubrania jakiego kupić, bializny, czy co, to jażeli nie beńdzisz mówić po litewsku, to stoj w kolejce choć ciebie niech zaduszo, a przez głowa bendo padawać, tylko kto beńdzie po litewsku mówić, o jak było. To przy sawietach to było.

A pani umie po litewsku?

Koje szto, jak mówi sie. Pionta przez dziesionta, troche rozumiem, bywa i telewizor puszcza po litewku, coś niecoś. Zanim nie było sowietów, to ja była tak - Polka i Litwinka. Na zabawach z chłopcami po litewsku flirtować mogła jak chciała, rozumjała wszystko, umiała. A ot jak zaszli sowiety, dużo przewrócili u mnie, zapomniała po litewsku mówić, bo po sowiecku, nauczyła sie pisać po rusku, nauczyła sie czytać po rusku, już teraz bendonc kobieto, ot, to już właść wyszła taka. A jenzyk mnie rosyjski był bardzo letki. Choć ja teraz powiem szczerze, ja teraz w ogóle rozmawiam nie wiem po jakiemu, niepawidłowo pa polsku, nieprawidłowo. Oj, nie, pani, daleko do polskiego jenzyka, o posłuchać jak po polsku Polaki specjalnie mówio, mój jenzyk daleko od polskiego, mój taki wiencej do białoruskiego pochoży, nie czuje pani? Pani tylko tak chwali.

\section{A tutej po białorusku mówili gdzieś kiedyś?}

Po białorusku u nas, pani, tak miecha sie, po białorusku i po rusku, teraz i po litewsku, i jak chce pani, różnych ludzi teraz, różnych ludzi jest, taki jak m'userny jaszczyk, wszystkiego czego pełno, to tak.

A $w$ domach wcześniej to jak rozmawiano?

Po polsku, i teraz, gdzie Polaki, liczy sie i katoliki, tam po polsku. A gdzie już mieszane rodziny była, to już tam jak chcesz, po rusku i po polsku, umiejo, rozumiejo teraz, co nie rozumie, to choć na migi pokaży, a wszystko jedno zmówion sie. 


\section{Gdzie pani chrzczona?}

W Moskwie. Mnie malutku przywieźli, ja pamientam po wojnie, chodziła kwiaty rwać.

\section{A gdzie kościół jest?}

Rymszany byli, Dukszty byli, Widzy byli, nu a najbliższy ...Puszki, to już od jednaj parafii odebrany trocha, od drugaj, zrobili kościółak, to pani taka puszkowska, o co Puszki tutaj majontak, pani puszkowska postanowiła, żeby zrobić kościółak, bo tutaj była taka kapliczka, nu i tam para pochowanych na tym cmentarzu, a tedy do tej kapliczki dobudowali drzewniany, zrobili normalny kościołak, zrobili parafia Puszki. $\mathrm{Nu}$ ale tutaj ksiondz był, i organisto był, i zachrystjan, normalnie wszystko, wesoło było, pienknie było. A teraz ksiondz przyjeżdża tylko rymszanski, niedzielami, a tak jak jakie świenty ot bywajo, nu jeśli taka już roczna świenta, to też przyjeżdża na każda świenta. Nu ale jak kiedyś byli świenta tak, jeśli wypada środa, to ona i bywa we środa, a jeżeli przypada pjontak, to nie ładnie, to pośle suboty niedziela, to w pjontek i odbendzi sie. A to wszystko tylko niedziela i niedziela, wszystkie świenty odłożone. Festy o teraz o odby wajo sie, to tylko w niedziela i w niedziela. Powszednim dniem nic nie odbywa sie, to jedna, że ksiondz naszy trocha chorowity, ten rymszanski, nu i ma swoja parafja, znaczy Rymszany, tak on tyko już obsługuje nas. Z Rymszan przyjeżdża.

Po polsku tu nie ma mszy?

Tu po polsku bywa jak on przyjeżdża, a w Rymszanach po litewsku, tam nie m'a po polsku, a tutej po polsku. Ji to jak czytał ewangielija, to przeczyta po polsku, a późnij przeczyta i po litewsku. Mieszajon sie i Litwini, tak widzisz zrobiona tak, że może oni co nie zrozumiejo po polsku, to czyta po litewsku.

A do pierwszej komunii, do spowiedzi, to jak uczono?

Uczono po polsku katechizmy, uczono, kiedy ja dochodziła do spowiedzi, to chodzili dwa tygodni codziennie do Rymszan na egzaminy. Znaczy, o, posiedzisz przez wieczór, z ranek powtórzysz i do Rymszan na egzamin. A wtedy znaczy wiela nas zebrawszy sie.... teraz już nie ma tego. Owszem, do spowiedzi prowadzo kobiety, ale tak ot, ja swojo nauczyła pacierzy, zaprowadziła do ksiendza, ksiondz zapytał sie tam co trzeba i ot, powiedział kiedy do spowiedzi, doprowadziła tam beż żadnego orszaku. Nie, już teraz nie ma w Puszkach, nie wiem jak w rymszanskiej parafji, a w naszej puszkowskiej nie ma... mało dzieci, mało ludzi, pani kochana. Tu teraz krong ludzi tak, jeden abo dwa, jeden albo dwa, w każdym domku. Mało już, prawda mówi, dwa dziadunia i bacia, nu to wnuków jeżeli doprowadzo, a tak już nie ma takich młodych, nie ma, i dzieci nie ma, i młodzieży nie ma i ludzi młodych nie ma. Tyko przeważnie stare. Nawet wienkszość domów pustych w ogóle stoji bez potrzeby. Przódy aby tyko gdzie domek został sie, kto gdzie wyjechał znaczy, to ten domek albo sprzedał, albo tak zostawił, aby tyko wyjechał, nu to tedy aby tyko kupić, a teraz darmo bierz, 
nikomu niepotrzebna. Nicht nie chce brać, nicht nie chce żyć. Trzeba pracować na wsi, a teraz już nie chcemy my pracować, nam chce sie, żeby manna z nieba sypała sie. A pracować nie, bo mazoli, bo cienżko. Nu cienżka, pani kochana $\langle$ praca $\rangle$, nu ale kiedyś i żyli, i biedni'ej ludzi żyli, ala żyli, rożżywali sia powoli, Boża mój drogi, jak cienżko była po wojnie. Nu pa tej to już nie tak, bo nie tak tutej poniszczyło sia, a jak tamta wojna już opowiadali wszystko było poniszczone, nie mieli za co zaczońć żyć, i zaczeli, pomału, pomału i rożżyli sie.

\section{Czy rodzice dużo ziemi mieli?}

Pieńć hektary, ala wszystkiego już było, i z błotami, i z łonkami, i z wszystkim czym. Mało było ziemi, tylko było ornej dwa hektary, to my wiencej z mamo jak padrosłam ja, na robota i na robota do puszkowskich chodzili, do panów, to ogrody pleć, to siana grabić, znaczy suszyć, nu i na zarobki. Padrosłam już jak zaczełam umieć podymować żyta spod kosy, to na żytożniwo wszeńdzie, na roboty. O co ja tak ziemia lubiła, lubia i teraz.

\section{Jak żniwa kiedyś wyglądały?}

Bardzo pienknie, pani. W każdej wjosce, jak konczajo żoń́ żyta, ot, jeden gospodarz konczył, biegli drugiemu pom'oc, żeby, znaczy wszeńdzie, dażynki robio, śpiewajo pieśni pienkne te dożynkowe, mocno wesoło i pienknie było kiedyś, teraz wszystko wykasowane, nic nie ma na świecie, absolutnie. Tak żyjisz człowiek zakryty jak u jakaj budce, nic nie widzisz, nic nie słyszysz, ni młodzieży jest, ni muzyki gdzie jest, ni yarmoszki nigdzie nie usłyszysz, nigdzie nie usłyszysz żeby panienki śpiawaliby, chłopcy śpiawaliby, dzie pad żytam chodziliby i tak spacerowaliby latno poro. Toż kiedyś u nas jak pienknie było, zbieramy się, jidzim jak to mówi sie pad żyta, nu ot żyto jak pożenta, chodzo, spiewajo z muzyko, z harmoszko, grajo chłopcy, spiawamy. Jak było wesoło, teraz nie ma nic z tej wesołości, absolutnie. Pomimo tego nie ma młodzieży, wszystka młodzież to w szkołach, to wyjechausszy gdzie pracujo, wyuczyunszy sie i wszystka młodzież, i żonate i panienki, i chłopcy, wszystkie pa g'oradach pawyjeżdżauszzy, nicht nie chce w domu, tylko stare rodzicy pozastawausszy sie i żyjo.

\section{Teraz chyba i pracy nie ma?}

$\mathrm{Nu}$ teraz i nie ma, a gdzie, jeszcze jak był kałch'oz, pracowali u kałchozie, nu to jeszcze pracowali, kto trachtarysta, kto kambaj'or, chto da palawodstwa, kto z koniami pracował, jak to mog, tak, ale pracowali. Nu a jak teraz i kałch'oz rozdrapali, nu nic nie ma. Teraz żyjim tak, jak kto chce, czyj jak rozum wynosi, jak głowa kamanduji, tak i żyjim.

Jak zaczynali żniwa, nie stawiali pierwszego snopa do kąta?

Nosili, sama piersza garść jak skroji, zwionży i tedy przynosi do domu i w końcie postawi. Gopodyni znaczy tak robiła. A my żeli, sierpem żeła i spad kosy padbiarała, umiała to wszystko, pracowała, lubiła to wszystko, wasoło było i nie czuła sie men- 
czenia, o co jest. Jakości z cheńcio to wszystko robiła sie. Dożynki, tedy wianak wijo. Już jak konczo żyta, tady zwino wianak gospodyni z kłoskou żyta z kwiatkami, a na gospodarzu pas taki zrobio, też tak samo z kłoskou, nie tak, ale z całego żyta i tedy kłosy zwionżo kwiatami, a ta słoma przeplecie $\mathrm{z}$ kwiatami.... na pierszym snopie nie byłam tak specyjalnie, pod koniec była.

\section{Czy gospodarz musiał poczęstować pod koniec żniw?}

A jak, pani, urzondza sie, i wódki, i zakonski, i różnego czego, jak ma, tak szykuji wszystko, też i muzyka sprowadzo jak bywa wielka tłoka, o jak u pana robili, dożynki byli, no to i muzyka sprowadzi, młodzież..., wieczorynka zrobi..... napili sie, kaczali sie... pienknie było, czysto było, a teraz to już wszystko brudno, niepienknie, paczszeć nie chc'e sie.

\section{Wieczorynki urządzano często?}

Każda niedziela, to $\mathrm{w}$ jednym miejscu, to $\mathrm{w}$ drugim miejscu, po sonsiedzku. Wszystkiego, wie pani, była, fanty nazywali sie, zbierajo znaczy, jeden wybrany, para wybrana i zbierajo od wszystkich kto co moży podarować, tedy za te fanty, znaczy liczy sie te, musisz wykupić. Ji o tedy przeznaczajo różne takie zabawy, co, znaczy, żeby wykupić swoja chusteczka nosowa, czy tam jaka szpileczka. Pienknie była kiedyś, pienknia, teraz nic tego nie m'a. Ja nie wiem czemu tak, jest i kłuby, ale nicht nie organizuji pienknego, nic nie m'a. Napijon sie chłopcy .... i poszli. Rozpusta teraz. Kiedyś wie pani co, był styd, był yonor, był yonor człowieka, znaczy, to nie możno, to nie możno, to stydno, to bendo obmawiać, a teraz nic nie stydna. Teraz nie stydna i nie grzesznia, bo wszystko możno. Zmieniło sie i nie d'aj Boże tej źmiany. Zrobiło sie to, że beńdzi kara z toj wszystkoj zmiany, bo już Pam Bóg wiencej patrzyć tak nie moży. Jak ubierajon sie, jak pokazujo różne te kancerty swoje pa talawizaru, to paczyć nie chce sie. Nie daj Boże. Ale co zrobisz, wszystko modnie, a co modnie, to i pienknie. Nu i jak mówić, nie ma co i mówić, trzeba godzić sie. Wie pani, u nas nie ma młodzieży, nie ma na co patrzyć. Młodzież nasz po mjastach, to gdzie u krewnych, to gdzie kto uczy sie, to gdzie wyszedszy zamonż, to gdzie na robocie i wszystko młodzież nie m'a, nie m'a na kogo patrzyć.

\section{Jak pani męża poznała?}

Tak poznałam ja pani .....flirtujonc, takie karty porobione byli u nas, u dziewczynkach, koleżanki znaczy sie po sońsiedzku mieli karty, jak zbierzy sie młodzież, tedy flirtujim, posyłamy te karty, co tam napisane, nu i tak zmawiamy sie. Napiszym tak, czy moge przyjechać pojutrze, a to było tak, był wtorek, wtedy środa, na czwartek przyjechać. A to czwartkami przyjeżdżali u swaty. Nu to mnie tak napisał, nu a ja jemu odpisała, od ciebie zależy, chcesz przyjeżdż'aj, chcesz nie przyjeżdżaj. Tak i znajomości nie miała i lubv'i nijakej nie miała, drużby nijakej nie miała. Miałam chłopców, ale w dalszych, dalekich, jak to mówi sie, z dalekich stron miała chłopców. 
A ot wyszła tak, co przyszła za niego zamonż wyjść. Nu i ot przyszad ten czwartak i ja wieczoram szyła bluzeczka, na wesele szykowała sie do koleżanki, miało koleżanki być wesele, i ja szykowałam znaczy bluzeczka ta i wieczorem, przy ogniu, mama już położyuszzy sie spać odpoczywała, ja myśle sobie, czy spełni sie ten czwartek. I spełnił sie. Jedna furmanka przejechała $\mathrm{z}$ dzwonkami i znaczy ta pojechała do mojej tej koleżanki, gdzie wesela miała być, już młody pojechał tam do niej, drugie dzwonki, drugie dzwonki do mnie na podwórko, znaczy spełniło sie. I ot jak przyjechał, pani moja, on moj - ja jego. O taki los, sondzenie Boże. Ni drużby, ni co. Znać ja jego znała, no ja z nim nie chciała. O co zrobiło sie. A o co stało sie, sondzenie od Boga. I przez dwa tygodni wesele, nawet przez dwa tygodni, nie przyszło sie i trzech zapowiedzi wyczytać. Szybko. Raz dwa i un damki. Nu i pożenili sie tak, żyli, żyli, dożywali. Ja była w Kowaliszkach, a on w Mejsiszkach, niedaleko wjoska, Wojciszki, jego znaczy wjoska, a moja Kowaliszki.

Czy w tych Wojciszkach mieszkaja jeszcze ludzie?

U Wajciszkach, ja pani, wiela jeszcze została sie, tak, Lionia Stafanska i Maniszeski, o, i wszystko. Kto do Polski powyjeżdżał, kto poumierali, nic nikogo nie zostało sie. Dwa domki, które żywe. Po polsku tam. Wie pani, jak powiedzieć, jeżeli... oni w prawej stronie, ot jak, jak do Puszek dojado, to wtedy od Puszek, znaczy majontek Puszki, bo kościoł Puszki też, kościoł Puszki, a tu majontek Puszki też tak sama, to u Puszkach pawraca sie tedy na Wajciszki, na Maniuki tam wjoska. Maniuki to już liczy sie tam na Białorusi, o da Wajciszek to można.

\section{Gdzie jeszcze jakie wioseczki, gdzie mówia po polsku?}

Liczyło sie kiedyś wioska Ungrełany, to to od Mejkszt, a teraz kto u Undrełanach mieszka, na kolonji Urban mieszka, tam po polsku, nu i liczy sie u wjosce Hela, o, to liczy sie Undrełany, nu a tu już jeszcz'e Undrełany jest, to tu Bogdan, bo to kolonji takie, już jak da Trukan, ale tu już ruski dom. A tu wo Trukany, a ot w Trukanach da kogo pani może pójść, Trukany i Barówka to nie m'a ludzi. U Barówce tyko o dwa domy, o co teraz pogrzeb był w sobota, spogrzebili człowieka w Barówce, a drugie znaczy dom Barówki, co moj był, gdzie ja mieszkała. Tam już zarosło u nas mocno, zarośla wszeńdzia, już i nie było gdzie ni wjechać, ni wyjść, wszeńdzia drogi pałamane byli, mosty trachtarami jak kałch'oz był, tak nie można było nigdzie ni wyjść, ni wjechać bez butou przez całe lata, no to tedy my przejechali tutej un Borówka, i przewieźli swoj domak stamtond. Borówka. Nu to ten Apalejicz znaczy, co umar, teraz o spogrzebili, to została sie Marysia i Bronia. Nu przychodzo jednej znaczy sie wnuki, a drugiej liczy sie plemienniki. Zostali sie inwalidy, jedna chroma, a druga skaleczyła sobie bjodra, waliła sie i trafiła na coś twardego i skaleczyła, i wo teraz chodzi tyko z taboretko, o jak chodzi. Nu i o tej kobiecie, która z taboretko chodzi, jej monż w subota spogrzebili. $\mathrm{Nu}$ a tutej już jedna menżatka, a druga stara panna, tej Marysi znaczy wnuki, córka jest, nu ale córka mieszka w Snieczkusu, jednym słowam niedobra córka, nie patrzy 
nic, tylko to, co oni stare patrzajo jo, ona nie pracuje, z menżem rozeszedszy sie, tyko chłopcy dwa, jeden kowaler, a drugi jeszcze trocha młodszy. Nu to jednym słowem, moja kochana, nu po polsku tedy, te obie siostry. A zieńć był ruski i już córka wiencej po rusku, i wnuki wiencej po rusku i w dodatku teraz rozeszła sie. Żyje jak jej podoba sie, ja nie obmawiam, tyko mówie to, co jest, prawda. Nu a te wnuki przyjado tutej, nu babcia, i dziadunia, i ciocia swoja pensja co otrzymujo, dla jich dali, te powieźli, maszynami jeżdżo, żyjo chodźby co. A te staruszki jak ... Nu o teraz gospodarz umar, teraz jak oni bendo staruszki te żyć, nie wiem. O te Polaczki i wierzonce, a drugi dom, dzie ja mieszkała, o, to tam ruskie.

\section{A kiedy pani do Mejkszt przyszła?}

Do Mejszt przyszła, wie pani, tak o ja teraz sześć, dziesienć, znaczy szesnaście i o teraz trzeci rok, dziewietnaście lat już beńdzie, ja teraz rok już nic nie pamientam, pani kochana, u mnie o tutej sz'aryczki już znosili sie, ja nic nie pamientam, już laty powiedziać nie moga, tyko tak. Z menżam jak przejechała tutej do Barówki przażyła sześc lat, umar monż moj. Tedy przażyła bez menża dziesieńć lat jedna, nu szwagiar był, siostra, pomagali oni mnie, nu i przażyła dziesiańć lat, nu tedy szwagiar um'ar, tedy siostra została sie jedna, ona mnie sprowadziła tutej, to ja trzeci rok tutej żyje. Umarszy siostra, nie ma, zato ja ji jedna tu ji żyja, ja tu stróżówka teraz tego majontku jichnego, o co jest, prawda, moja milanka. I jednej, jak przyjeżdżali tu do jej, jak on'a żyła, to przyjeżdżali każda niedziela, co tydzień, a już tedy, może co nie wyszła, co dwa tygodni, to choć bendo dzwonić co drugi dzień. A jak już mnie sprowadziła, to tedy już nie tak czensto zaczeli przyjeżdżać, ale wszystko jedno co dwa tygodni.... Jego wszystka robota, wszystka praca, to i dom zbudowany, zbudowany to już z majstrami, pomagali, ala później, znaczy wykonczenie domu, wszystko, plity, wszystko on sam. Już on nikogo nia najmował. A kiedy on umar, cienżko zrobiła sie, ona była pani za jim, wo co jej. A jak on umar, ona mocno przeżywała, nu to ledwo, ledwo jeden rok bez jego przeżyła, a wtedy zaczeła do mnie co drugi dzień przychodzić, przych'odź i przych'odź do mnie, beńdziem żyć we dwióch, co tobie tut jednej żyć u Barówce, nam beńdzie wesel'ej tu, przych'odź. Nu ja przyszłam do niej, przyszła, przyjeżdża, co lepszego, wszystko przywiozła tutej, a domak sprzadała. Tak półowa gospodarki wszystkiej i naczynia jaka gdzie co, półowa została, co niapotrzebna, .... co potrzebniejszego mniej wiencej, co lepszego, a reszta zostawiła. Nu tylko znaczy ja te piniondze jak wzieła, wszystko i oddała jejnemu zieńciu, starszej córki. Nu i ja została sie tak jak stoje, tak i żyła. Nu, ja trzymała jeszcze krowa tam, mleka zdawała, miała z czego żyć, nu i przyszła ja tutej żyć. Ona przeżywała, nu co jej zrobiła sie, nogi zaczeli boleć, ot zaczno palcy bolać, tak co mówi ja nie moga wytrzymać, mnie jak przy jakiej żelazie goroncej przytulona ta noga, znaczy taki bol. Ona cierpiała, cierpiała tymi nogami, nu to jeden raz schwyciunszy była, ja mówia, moża z nerwaun, czy co, jak to, tromb krwi jej był papatrzy sie, nu tyko dobrze, nie do serca, ale do płuc, 
nu to prendko padzwonili jichnym, momentalnie przyjechali i jo pawieźli u Wilna da doktoraun, ... wyleczyli, przyjechali. Wszystko jedno nogi jej tej dokuczajo, nu to ona wszystko cierpi, jim nie chwali sie, a mnie mocno biaduji. Ja mówie, Jania, pisz jim, jedź do balnicy, mówie, leć sie ty, mówie, co ty możysz cierpieć noc i cierpi, prost chudnieji sama, martwi sie tak przażywa, nu bol.. Praúda, przyjechali, pasłuchała, padzwoniła ona jim, przyjechali, zabrali, pawieźli da balnicy. A tu została sie, aha, jak ty zostaniś sie, krowa została sie, pośleż roku już, jak ty beńdziesz tu robić. Ja mówie, ty nie biad'uj, ja pamiendzy ludziej żyje, ji co jakiego mnież ludzi pomogo, jak mnie co trzeba beńdzie, a tak mówie, ja żywa benda, lenkac sa ja nie lenkam sie, absolutnie nikogo, nigdy nie lenkam sie, nikogo. Nu ji tedy znaczy przyjechali, pawieźli do balnicy. Tydzień czasu on'a odleżała u balnicy tam, z tyma znaczy nogami, nu ji przyszła sie, te dzwonio wszystko, mówio jak, ja mówie jak, jak, lepiej, lepiej, ale ciocia, czy można jeszcz'o na jeden tydzień, znaczy jej zostać, jej druga zaczeła noga gorzej boleć, znaczy już poszło ad tych palcau, łydki zaczeli boleć. Ja mówie, niech'aj beńdzie, ile ona chce, żeby tyko zdrowa była, aby tyko jest rada, że pomagajo, i co pani powie, znaczy na drugi tydzień na poniedziałek mieli jej szukać jakiego tam znów trombu, jakiego co oni tam przyznawali, znaczy, wychodzi, śpiekszy sie krew jaka chadziła pa żyłach jej. I to było na Kaziuka, czwartego marca, o, i rano wstausszy ona, co jej było znaczy tam, czy ona do tualetu, czy ona do dzwonka znaczy powinszować, znaczy zieńcia brata, bo był Kaźmierz. Dzie ona szedszy, na korytarzu, i nieżywa znaleźli. O jaka śmierć, jak laczenia. I tydzień przelażała u balnicy, nic nie robiona. Czego było brak, widocznie, pa mojim sumieniu, czego to było brak. Nu jeśli dzień, dwa, trzy, toż musieli analizy wszystkie przejść, prawda, wszystko przeleczyć, przeświecić. Ceły tydzień czasu przeszło, na drugi tydzień przakulili sie i jeszcze do mnie podzwonili, czy można. Jak ja pawi'em nie można, jeśli ja robia, to ja co powi'em, że nie można, bońdź, tyko lecz sie, a wo jak, cudownie, pani moja kochana, cudownie. Cud Boży razłonczył jo ze mno, a wzioł monż jo, że on'o, przeżywała mocno. Wprost monż zabrał jo, i to wszystko. Tak ot, moja milanka, i ja czekam wiadomości dobrej, ażno patrze zrano przyjeżdżajo do mnie, na Kaziuka. Co jest, mówia, co stało sie, czego wy przyjachali. Jania umarła. Ja mówia, u was na rencach. Wyż powieźli do dochtoru, leczyć, jak ona mogła, mówia, umarć. A jaż nie winna, czym ja winna, adpuściłam. Jeszcze ona przażywała, jak ja dam rada, tu i krowa, i wszystko. Później, a ja ji dała rady, Pam Bóg dał wszystko szczeńśliwa daczakała, i ciołaczka odłonczyłam, i ciołaczku pojiłam, mleka do mleczarni woziłam, robiłam jak trzeba była, wszystko czakałam, niech Bóg da tyko żeby jej zdrowie, onaż to młodsza ode mnie.

\section{Dawno umarta?}

Już trzy laty zaraz bendo na Wielkanoc, na Kaziuka liczy sie, nie na Wielkanoc. Ona była trzecia, ja sama starsza, a tedy druga siostra un Polsce wyjechaunszy, też umarszy, już nie ma i ona trzecia sama. Na dziesieńć lat ona ode mnie młodsza. 
Ja siedmnasty rocznik. Ji ot i czemu Pam Bóg tak zabrał, niech'aj mnie zabrałby, poco ja żyje, dla kogo ja żyje, na co ja potrzebna komu. Nu ja nikomu niapotrzebna. Wo tylko ja potrzebna teraz, że ja domu pilnuja, i po wszystkim, nu a tak co ja potrzebna. Pani kochana, a on'a, prawda synow i córak ma, i wnukau ma, jak to mówi sie i byłaby żyunszy i żyusszy. A wo jak Pam Bóg zrobił, co bendziesz mówić, tyko ja całe szczeńście Bogu dzienkuje i modlem sie każdy raz, i Bogu dzienkuje, że jo Pam Bóg tam zabr'ał, a nie tutej, nie przy mnie. Kto wie, co na mnie myślelib, kto wie, a może jo czym znerwowała, a moża ja czym nie dopomogła, a może co, pani kochana, co można wiedzieć, mało co siostry. A jak na swiecie różnie bywa. Ja jak mówi sie, upadłaby nieżywa i ja nie dokazałaby, że ja niewinna. A jak tam, ji winowajcy nie ma. A co tam było, to chto jego wie. Nic nie mówili, absolutnie nic nie mówili, ja to już i pytała sie, i wszystko, mówie, nu tak jak ona czuła sie, możeż ona wam co mówiła, czy ona gorzej czuje sie, może ona wam co mówiła. A nic ona tak nam nie mówiła, tylko Ela, już ta młodsza, co u Kownie żyji, to ta mówi, nu tylko mnie na pożegnanie, jak byli wieczorem, przy pożegnaniu mnie powiedziała tak: 'Elaczka, tyko dzietka ty nie przeżyw'aj mocno, tyko ta słowa mnie powiedziała, ja, mówi, tyko pamientać benda później, nie przeżywaja a za co nie przeżyw'aj, nie wiem. Nu moża ona czuła sie, moża ona wiedziała, a dochtory, pa prawdzie mówionc, widocznie nie paczszali, widocznie za mało była. Nu ja mówiła i mówić benda, nu ale jakżesz można za mało, to jeśli u poprawa ona szedszy, paczszaứszy jo czeńści'ej, za jakie trzy dni, nie prauda, tydzień czasu przeleżała i nic nie robili, nu. Nu i co tedy dawać im wiencej, kochane moje. Nu co, ot ji zrob, ad śmierci nie adkupisz wszystko jedno. I moża byliby i daứszy, moża byłab umarszy nic niawiadomo. A dawać też. Dać, to trzeba skond to mieć, niaprauda, nu wot i bońdź mondry człowiak. I wot moja pani kochana, wot jaka życia. I ja została sia o sieroto, jedna. Sieroto, gorzko sieroto. $\mathrm{Nu}$ ot ja teraz tyko co dostaje, osiemdziesiont cztery lity. W kołchozie ja nie wypracowała, monż pracował w kałchozie jak był, monż chodził, pracował, znaczy, normalnie. A ja nie pracowała, ja była domachaziajka liczy sie, nie kałchoźnica. Ja nie m'am trudadni'ej, mnie i nie ma pensji. To jaka u mnie teraz pensja, u mnie pensja tylko sielsawiecka, zapomoga, a ja adzinoka, bez rodziny, osimdziesiont cztery lity, czternaście centy. Wo moja kochana, i o trzeba przaż'yć. A co chata sprzedała, addadziona plemiannikam. To jeżeli psu rzucisz kiełbasy i zje, to nie weznisz od jego. To już ja teraz też tak samo, nie weznasz ja tych piniendzy, prawda. Nu ja nie głodna, żyja, jeślib ja nie miałaby, to oni musielib dać jeść. A tylko kury, miałam i psa jeszcz'o, ale o tamta niedzielka zakopała biedniażku, stary. Nu ji teraz tyko kury, ji wot moja cała gaspodarka. Wie, pani, już nie mogłabym, krowy ja już nie zdołam wywodzić, wyprowadzić, zato, że ja nogi chore mam. Jedna noga i druga kulawa, ... ona u mnie nie ma siły, ta o noga. A ta ... w ogóle boli w kościach, ta nie spuchnienta, a ta o spuchnienta. Ot jaż mówia, ja nog nie mam, ja z pałko o chodze. Mnie jak ja ide, mnie palcem chto popchnołby i ja powaliła sieb, ja nie mam żadnej 
siły w nogach. Po drabinie już ja nie polaze, po schodach to już ide tak wo jak kot na przod, nie pójda pa schodach normalnie. Nie mam siły już. Ale trzebaż, ogrody posadziło sie, trzeba i pleć, trzeba. On'i sadzili, ja nie sadziła, beńdzi dla mnie, i dla 'jich, już nie trzeba beńdzie. Nu tej, co un Wilni, to tej niekoniecznie, ta ma dacza, ma ogrody. A tyko co u K'aunnasie. Ot, moja taka życia. Ab siestry to ja nie moga, nie moga zapomnieć, że znaczy na rencach u doktorou umarła, nu jak to mogła być. Żeby powiedział, o tu zawieźli, o tu i umarła. Nu to znaczy nie zdonżyli, teraz tydzień czasu przetrzymać. Koniecznie, sondzenie może, a może sondzienie... Po jedno pani, po druga ja co chce powiedzieć, jak on'a, znaczy mjała taki nerw, że on'a przeżywała, nie mogła tego darować, jej nicht nic nie pomogby, praunda, praunda, jej już nie była pomocy, jej tylko śmierć była pomoc, o tak. Bo jeżeli chto jeszcze człowiek, z takim myśli, a możesz jeszcz'e pomoży, może jeszcz'e i zdrowieje, a on'a, już on'a ni w co nie wierzyła, już on'a tyko to myślała, co nie m'a Julka, nie chcem i ja żyć, o tak nie ma jego, nie trzeba i mnie żyć. Akurat chwała Bogu, że udało sie córku tu młodszu sporzondkować tamta laty jeszczy, jeszcze na swadźbie była pajechaunszy, też cały tydzień odpuściłam, pajechała. Jeszcze uporzondkowała córek abiedwich, i dobrza, co poszła, już tam odpoczywa bez kłopotu, nie myśli sie, czy co rośni, czy nie rośni, czy mokra, czy sucho, wszystko dobrza.

\section{Jak obchodzono Boże Narodzenie?}

Pani, ja powiem tam z swojej rodziny ja Bożego Narodzenie nic nie moga opowiedzieć, żyli bardzo skromnie, nie było z czego, to ni choinki nigdy nie szykowałam, nic takiego. Tylko jak, wiadomo, wigilja. Wigilja szykowała mama, wieczny pokoj, szykowała, jak to mówi sie, jak umiała. Ja tak samo teraz wigilja ta robia, szykuja, co umiem, co wiem. A Wielkanoc, Wielkanoc tak, chodzili do kościołu wieczorem na nabożeństwo, nocowali przez cała noc z mamo w kościele, aż do Zmartwychstania. Przeważnia tak. Kani'ecznie, nie każdy, ale tak, komu, jak mówi sie, chciało sie. Przyjeżdżali z kościoła z rana po razarekcji tedy już świencone jedli, jajkiem świenconym dzielili sie, nu i co było przyszykowane, to jedli. Jak komu kieszeń wynosi, chodźby i na ziemi... Bogaciejsze wiencej czego mieli, a biadniejsze mniej czego mieli, ale zawsze to bułka była, jajko zgotowane, farbowane byli, prosiaka jakiego zakoli sie, kapczonki zrobio, ot, kto co miał, tak i szykowali, tak i przeżywali.

A na wigilie jakie potrawy robili?

Potrawy to tak, co wychodzi komu, jak kto co ma, jaka drużyna. Jeżeli wielka drużyna, wiencej czego szykujo, wiencej tedy wszystkiego szykujo, różnych potraw wymyślajo. A jak mała rodzinka to bywa, tak co tam czego naszykujisz, mało czego, kisielu zgotujisz, kampocik zgatujisz. Z' jagód, żurowiny albo bywa kompoty jak te robione, wareni, gotowane jagody, to z' jagodów gotuje sie kisiel. Bywa kisiel owsiany, ja o żyła z menżem, to mieli tam kisielak był, kompocik jabkowy ... nu i opłatek, co wiencej, ryba jeżeli jest, albo śledź. Nu jaka drużyna, jak wienksza drużyna... 


\section{Czy pierogi robili?}

$\mathrm{Aj}$, piekć pierogi. Też tak samo, skromnie, jak nie ma rodziny, nie ma komu jeść, nie ma co wymyślić. Nie pochwalam sie, żeby ja coś, tam jakie torty wymyślała, nie, nie robiła tego.

\section{Czy chodzili na Boże Narodzenie i śpiewali pieśni?}

Nie, nie chodzili. Tego nie była u nas. Tej tradici nie odbywało sie. Na Wielkanoc to chodzili, tam nazywali lalauniki. Nu to ot chodzili chłopcy, i z harmoszko s'piawali, grali pienknie, o to to odbywała sie, a na Wielkanoc, na pierszy dzień, w pierszy dzień wieczorem. To chodzili, śpiewali piosenki. Różnie była, jak kto zapraszał, bogaciejszy miał wypić, i w domu młodziż była, nu to tedy pośpiewajo tam win'o zielone, to tedy już zaproszo do domu na pewno, nu a jak mniejsza dzie rodzina, skromni'ej chto żyji, nie wszystkie bogate byli, to tedy nioso talerzy, tedy majo jeszcze butelka wina.

\section{Jak jajka malowano?}

Jak w mojej rodzinie, to malowali tylko i daże nie farbo, łupinko od cybuli i bardzo pienkne czerwone, jeżeli wiencej włożysz, to bardzo ciemne, a jeżeli niedużo włożysz, to takie jak żółciankie, jak chconc, rozumiecie.

\section{Czy byly wzory na tych jajkach?}

Nie, my nic nie robili, wo tyko chto robil, to plemienica teraz ta moja starsza, to ta jak była przyjechawszy jeszcz'e przy mamie, teraz to ona Wielkanocy była, to ona nic nie robiła, nie przyjeżdżała daże, tam u siebie już porzondkujo sie z gościami, do mnie nie przyjeżdżajo, ni jedna, ni druga. A póki mama była, to przy mamie byli przyjechauszy, nu to robili, to oni wycinali tam z papieru i abklejali sie jajki, do ponczoszkau składali, tam różne unzory robili, to oni malowali. A ja to na razie tego nie robie.

\section{Może jajka kaczali?}

Nie, u nas nie. Wo jak żyła ja jeszcze w Wajciszkach z menżem, to zbiarali sie sonsiedzi, kaczali, taka korytka i puszczali, kaczajo, tedy u karty grali, kto wygra jajko. Chto jej wie dlaczego, nu ot prost zabawa taka, puszczajo jajka, jeden puści, tedy drugi puści i jajka u jajka popadni, to znaczy tedy zabiera ta jajka, wygr'ał, ale jeżeli mimo pójdzi ta jajka, drugi puszcza. To samo jak w karty grać, jajki puszczać to samo. Po prostu gra taka.

Nie obchodza jakichś lodowych dni?

Ki'edyści, to tylko świentkowali już, świento było kiedyści wielkanoc świeńcili cztery dni, pierszy dzień, później drugi dzień i trzeci dzień, drugi młodzienkowy, a trzeci dzień...wiem, że cztery dni świontkowali. To bywało, mówion, trzeba świontkować ten dzień mocno i modlić sie, Boga prosić, żeby gradu nie byłoby, Pam Bóg 
daji grad tedy, wybiwa wszystko. To już mocna wierzonca byli kiedyś ludzi, a teraz, pani kochana, teraz nicht nic nie wierzy. On na sobie, grzmota, on'a sobie, grad on'a sobie, to nic nie wierzo teraz. A kiedyści wszystko wierzyli, oj wierzyli. Wiencej Bogu wierzył, wiencej, jak mówi sie i mjał, a teraz.... nic nie wierzo.

Jakie jeszcze wielkie święta były?

Nowy Rok bywa, Trzy Króli bywajo. Przeważnie jak w szkołach, to robili maszkaradny wieczor taki, nu to różne ubranie tam takie robili, smieszne, ubierali sie różnyma, maski takie robili, ale to już w szkola była. A na wiosce nic ...

Nie piekli ciasteczek na Nowy Rok?

Jak u kogo, gdzie jaka trad'ycyja. Nie chodzi sie na ten, już ostatna kucyja, nie chodzi sie, nie pożycza nicht nigdzie niczego, nie chodzi, nie dokucza. Nu nie wiem czemu już taka trad'ycyja była, żeby być w domu przy sobie.

\section{Wróżby może były?}

A, to na Andrzeja, to wróżyli ki'edyści, ale jakie tam wróżby. Na woda puszczali, świeca palili, jak co skreńci sie z tego wosku, nu tedy wyobrażajo sobie, nu tedy co jeszcz'e robili, papier gazeta palo, jakim czubkiem co zrobi sie, tam to na koniu jedzi rycerz jaki, to to wymyślajo sobie, nu taka tyko zabawa. Albo co jeszcz'e, pod łóżka stawili kubak i ze słomki mościk, znaczy kto przeprowadzi jak zaśnisz i beńdzisz śnić kogo, kto przeprowadzi przez most, ale już tak, żeby nicht nie widziałby jak położy to chto, jedan jednemu tyko podkładajo, to nie to, co sobie. Sobie nie, ale jeden jednemu tak podkładajo i żeby znaczy przyśnić sie.

Nie stuchano jak psy szczekaja?

$\mathrm{Nie}$, nie robiłam ja tego. Owszem, mówili, że trzeba wyjść, i to głaunna, tam dzie parsiuczka na świenta kłuć, to znaczy tam. I bywa chto ...daleko, jak wiatyr bywa i smalo, to pójdzie tam słuchać, gdzie tam beńdzie ten pies szczekać. Nigdzia ja nia chodziła, to nia robiła tego. Robić to robili. Było takich, co robili, a czy później im to udało sie.

Nie liczyli w plocie tych...?

Śmieli sie, robili to ludzi, tyko, ale ja nia robiła tego. Płot obejmujo, albo pójdo achapka drzewa bierzy na renka znaczy niesi da chaty i wtedy liczy, czy pary czy nie. Jeśli para, to znaczy. A na pewna to wszystko spełniała sie, aj, nie wiem. To ja nia robiła. Tego to była, jak kto co zmyśli.

\section{Może zamawiano od chorób?}

A że zamowa, to zamowa jest, owszem, ja przyznaje zamowa. Osobliwie przyznaje zamowa, jeśli człowiek chory na róża, to już zamowa pomaga. Pani, to choroba zupełnie głupstwo zdaj sie. A ona bardzo zastraszyła. I ja sama, un tej samej wo lewej nodze mjała o tu koło kosteczki róża i żeby ja dochtoraun uzywaunszy, to byłaby do kolana nogi 
nie miaunszy, a jak ja pa dachtorach nigdzie, tylko pa tych, chtóre zamawjajo ad róży, a róża zamawiać to nie ma żadnego grzechu, bo to jest świente słowy, modlitwa albo do Pana Jezusa, albo do Matki Boskiej i która modlitwa odmawiajo do Pana Jezusa, a nie taka pomocna, która odmawiajo, zamawiajo do Matki Boskiej modlitwa, ta jest pomocniejsza, ta pomaga, o. I róży jest dwanaście gatunkoun, nie daj Boża, i to rany robio sie, wie pani i ot ciało gniji i bol człowiak odczuwa wielki i znaczy taka choroba. A dochtory nie przyznajo i nie umiejo leczyć, sposobu tego nie majo. Tak jak ad raka nie umiejo leczyć, tak ad róży nie umiejo. A tutaj tak samo. Ot ad raka jeszcze nie ma znaczy zamowy, nicht nie mówi, że kto by dzie zamawiałby ad raka. Ot jeśli zamawialiby ad raka, to i chorobau tych nie byłaby. A ot od róży zamawiajo, nu od róży to oni u nas zamawiała kobieta u Borówce, co ja mówiłam, dwie kobiety zastali sie teraz. To u tym domie, tam sonsiadka moja, nie z jichniej rodziny, ale sońsiadka zamawjała, ale ona umarła, a teraz syn jej zamawia, on zamawia. To jejna bardzo pomocna. Sztukienowa. A teraz tam Jan Sztukien u Śnieczkusu zamawia, to ot jejna mocno pomagała, ot jak on zamawia, syn ten. I o zamowa co, zamowa jeżeli chce kto leczyć, to musi być znaczy czy syn, czy córka, albo pierszy, albo ostatni. O tylko takie osoby mogo ad róży zamawiać. A jeżeli tam ot srednie, to nie liczy sie, nie pomocna. I na przykad ja sama sobie też nie zamówie, ja tyko komuś moge zamówić. Nie, nie umiem ja, ale znaczy ja sama sobie nie zamówie, ja tyko komuś moga zamówić, a sobie nie zamówie. Ona taka, ta róża.

Jak nazywaja tych ludzi?

Niby mówio i znachar, prosto z mostu, ten kto zamawia.

Czy jeszcze od czegoś zawamiano?

Zamawjano, $\mathrm{z}$ wiatru zamawjano, $\mathrm{z}$ wiatru też jest zamawiajo, jeżeli ot wjatrem człowieka sparaliżuji dobrze. $Z$ wiatru bywa różne też choroby. Też zamawiajo, ale $\mathrm{u}$ nas tego nie ma. Tu była o sońsiadka, ale daleko, ruska, zamawiała $\mathrm{z}$ wiatru. Róża i z wiatru. Tedy jeszcze od gadziny też zamawiajo ludzi. Ale o teraz jak gadziny też nie wiem nikogo tutej, w Maciunach tutej w wjosce starycz'ok taki był, to ten zamawiał. A teraz on umar, już teraz nie wiem, czy kto zamawia, czy nie zamawia. On zamawiał z ocz, jeżeli paszkodzi kto krowie, zepsuji kto, znaczy mleka krow a nie moży dawać i choruji bardzo, to znaczy on zamawiał z ocz i ad gadziny zamawiał. Paśla jego nie wiem, czy kto wzioł ta zamowa, to nie wiem.

\section{A byli tacy, co psuli mleko?}

Była, i teraz, pani, znajdujon sie takich ludzi. Zajzdrość taka, i przez ta zajzdrość, to już grzech śmiertelny robić. Ty człowieku wred, kopiesz jama, nie można to. Zamawiać od tego, to nie grzeszy, możno, o. Jeśli, znaczy, wred robić, wielki grzech. Ale co kto patrzy. Szczególnie to niedobre dni w świentego Jana, na krowy, szczególnie najgorsze, które wred robio, to te pracujo mocno. Jutro świentego Jana, 
to dzisiejsza ta wigilja świentego Jana, to mówi, nie można nic nikomu pożyczyć, jeżeli masz krowy, szczególnie na krowy szkodzi. Nikomu nie można nic pożyczyć, bo widzisz, mocno szkodzi tedy na krowy, mleka tedy psuje krowa. Nie dajo krowy, krowy chorujo, nu jednym słowem niedobrze. I to najwienkszy ten czas, świenty Jan i Pjotry, te wszystkie dni o takie, i przed Wielkanoco, przed wigiljo znaczy wielkanocno, nie bożonarodzenna, a wielkanocna, też nie trzeba. Nie pożyczać, nikomu nie pożyczać nic, to nie trzeba pożyczać ten dzień. To to już znaczy zabobony takie nazywajo. Dawniej z pokolenia un pokolenia. Jak Pam Bóg strzeża, to wszystko strzeżona beńdzi.

\section{A św. Piotra to wielkie święto?}

I teraz wielkie świento. Teraz wie pani jak mówio, jeżeli na świentego Piotra pójdziesz do kościoła i tak szczerze modlisz sie, to choć cały rok nie pójdzisz do kościoła, a jeden ten dzień świentego Piotra pójdzisz do kościoła i pomodliś sie, do spowiedzi pójdzisz, zaliczy sie tobie cały rok u świentego Piotra. I po religii u nas to. U nas wielkanocna spowiedź to przed Wielkanoco można iść znaczy ten tydzień jak o u poście, przed Wielkanocem i możysz iść do spowiedzi wielkanocnej znaczy całen czas aż do świentego Pjotra. Do świentego Piotra już ostatni twoj sezon wielkanocny liczy sie. Ale to już liczy sie, religji naszej, to liczy sie tak, jak tam cały rok chodzić do spowiedzi, nu jeden raz u rok trzeba na Wielkanoc, wielkanocna spowiedź adbyć sie, czy przed Wielkanoco, czy po Wielkanocy, ale on'a liczy sie wielkanocna. Już to prawdziwa taka tradicja.

\section{A co ludzie mówiq o różnych ptakach?}

O różnych ptakach to ja ji nic nie powiem, tylko jedno powiem, też, może to prawda, może to nieprawda, nu w moim życiu też było, a ja nie wiedziała, o. Zwiastowanie, dwadziestego piontego marca to bywa świento, wiecie, o, i ot jeżeli na Zwiastowanie mówi, beńdziesz brać jajka z gniazda, nu ot jak kury nioson sie, jajka z gniazda, to jak posadzisz kura, bendo inwalidy. Nie możno w ten dzień ruchać z gniazda jajka na Zwiastowanie, czy oni tam dużo naniesione, czy mało un gnieździe, niechaj stojo do jutra, a jutro wybierzysz i....A mnie było, ja wyszedszy zamonż już byłam i świakrowka była, jego matka i ja posadziła kury, i u mnie kury byli kalekie, dwie kurki kalekie. Jedna mjała dzióbek o taki o, na krzyż, takie paszczenka, to na krzyż taki dzióbek, i ona wyrosła, i wielka była, później zakroiłam wielku, ale do wielkości dorosła, jeści jadła ona, znaczy jej niedobrza była jeśli jejny dzióbak był na krzyż, czemu to, nie wiem. I bez moszki jednaj była, to o, dwie kurki takie. $\mathrm{Nu}$ to ot, mnie tedy świekrówka mówiła, że mówi, pewno ty brałasz jajki z gniazda na Zwiastowanie. A co ja wiem, nikt mnie nic nie mówił, ja i nie wiedziała tej wróżby, co ja wiem. To już teraz ot jak żyja od tego roku, od tamtej pory jak już mnie tak trafiła sie, to już pamientam, dużo komu mówia, ale śmiejon sie ze mnie. Może i nie prawda, a może i prawda. Mnie trafiło sie, a świekrowka mnie powiedziała, tak możesz 
to i praưda była, ja nie wiem tego. Nu ale teraz już robia tak, jak ona pawiedziała, żeby nie brać, nie biora i nic nie stanie sie. A tak wiencej nie. Tyko że Zwiastowanie, teraz Zwiatowanie wykasowane, nie ma nijakej świenty. A kiedyści Zwiastowanie było mocno wielka świenta, że mówi, nie możno nic pracować na Zwiastowanie, bo mówi tak, ptaszka, mówi, gniazdy i to nie wiji, to ptaszka i to rozumi, że ptaszki nie noszo gniazdy sobie, nic a nic nie szykujo na Zwiastowanie, spokój świenty. To możesz i prawda, mówi, że mocno wielka świenta. Kiedyści jeszce, jak i ja mała byłam, to musi przy rodzicach, to i mocno świontkowali, wszystko świontkowali, i Zwiastowanie, a teraz wykasowane, nic nie ma. Tyko to, co Zwiastowanie, a już tam nie ma takiej obowionzkowej świenty.

\section{A na Zielone Świątki?}

A na Zielone Świontki przystrajali brzozkami, gałońź wionzali, krowam wianki na rogi kładli a samyja znaczy pastuchi, żeby gospodyni syr daliby, o to robili, ale już to daunno, teraz już nicht nic nie robi, skasowane już to wszystko, a jeszcze za pamieńcio mojo robili, my same paśli znaczy krowy swoje, jak u Kawaliszkach żyła i przychodzi sie paść kolejka, nu to też przymanisz krowa i wianek zrobisz z brzozki i do domu... Beż żadnej wróżby, tylko że znaczy krowa przychodzi z' wiankiem z brzozo, gospodynia ser da tedy pastuchu temu, który pas, który wianek urzońdził krowie, to tyko podarek taki ot, ale beż żadnej wrożby. Ganki, brzozki przynoszo, przystawujo, taka już tradycja, u mieszkaniu stawili, koło łóżka, koło stołoun znaczy. Nu pachno brzozki pienknie, już taka tradicja.

Kiedy święcono zioła, kwiaty?

Raz świeńci sie Dziewientnik, o tu przeszły czwartek u nas przypadał, to w niedziela odbywała sie, Dziewientnik, to dziewieńć wiankaun, albo dziewień́ tych penczeczkau, a co to ma znaczyć, to nie wiem, znaczy świeńcili te zioła, ile beńdzim jeszcze świeńcić na Niebowzieńcie, pietnastego sierpnia, Niebowzieńcie Matki Boskiej, to też zioła świenco, ale już tedy ogrodowa, ogórki i marchew, i jabka, i gruszki, wszystko ogrodowe takie, a teraz o świeńcili kwjaty.

\section{A kiedy ten Dziewiętnik bywa?}

Dziewionty piontek po Wielkanocy, dziewionty piontek. Zioła świenco i tedy bywa jeszcze nabożenstwo, taka dzieciej małych, błogosławieństwa, też odbywa sie w ten samy dzień, na Dziewientnik ten. To to było jeszcze, jeszcze nie wykasowali, jeszcze to jest.

\section{Bociany, to dobrze?}

$\mathrm{Nu}$ chto jej wiedzo, nie wiem tego, nicht tego, takaj wróżby nic nie moga powiedziać, nic nie wiem, tylko jedno mówia, że ludzi kiedyś mówili, że jeżeli bocian z gniazda wyrzuci jajko, to na dobry rok, a jeżeli dziecionka wyrzuci, znaczy bocianiuk'a, na niedobry rok. W tym roku, mówi, wyrzucił dziecionka z gniazda un Mejksztach tam, 
stołowa tam, dzie była kiedyści stołowa, nu to tam jest gniazda, bocianiuk'a rzucił, to na niedobry, na głodny rok.

\section{Jakiego pani widziała pierwszy raz bociana?}

Widziała musi na gnieździe ja, szedła na poczta płacić za swiet, nu to widziała na gnieździe jednego, stał. Ja jedna, jednego i widziała.

\section{A jak kukułkę się pierwszy raz usłyszało?}

Kukułka, szedłam z chlewa i niosłam jajki, i usłyszała kukułka, to nie wiem, bogata, ci biedna. Piniondzy trzeba mieć w kieszeni, wtedy nigdy nie wyprowadzajo sie, ale ja piniendzy nie miała w kieszeniu, a tyko jajki niosła $\mathrm{z}$ chlewa. I to dwa laty kukułki nie słyszała i nie wiem czemu. Mówio, kukuji, kukuji, a ja nie słyszała. W tym roku słyszała kukułka, ot nie wiem czemu, czy uszy moje zaczeli słuchać, ci kukułka gdzie blisko kukała, ale słyszała, i nie jeden raz, kilkanaście razy słyszała, ten samy dzień słyszała i późnij kilka dniej tak słyszała. A dwa laty i nie słyszała kukułki, to mówia, musi nie kuka, mówi, kuka, ja nie słyszała.

Do kiedy ona kuka?

Do Piotra, od Jerzego do Piotrego, jej sezon. A późnij już ona... ptaszki. Ona tylko faktycznie robi sie taki malenki karszun'ok, ptaszeczkau malenkich tedy drze on. Ona jakości niedobra, ta kukułka. Wieczny pokój papa moj mówił, że to znaczy kukułka, to jest wdowa kobieta, żyła z menżem mocno niezgodnie, jak legenda była, znaczy opowiadał, i mocno niezgodnie żyła i ot wypeńdziła znaczy z domu menża i nie dała jemu kluczy, zato ona teraz ku- ku, ku-ku i nazywa Jakub, Jakub. Nam zdaj sie ku-ku ona mówi, a on'a Jakubem swego menża zwała. Jakub, Jakub, masz klucz, masz klucz, a on'a bywa tak znaczy kuka, kuka, tedy jakości tak chartija cości, słyszeli może kiedy, nu ot ona znaczy, masz kluczy, już menżu kluczy oddaji, że znaczy ona niedobra mocno żona była, to o kobieta i niedobra żona. To papa moj wieczny pokoj mówił. Nu Pam Bóg jej wiedzo, czy to praunda, czy nie praunda, nu to kiedyści wiedzieli ludzi, to może praunda. Bo kiedyści wiedzieli ludzi swoj wiek, wiedzieli kiedy śmierć przyjdzi.

\section{Bibliografia}

Karaś, H. (2001). O sytuacji języka polskiego na obszarze smołwieńskim na Litwie. Prace Filologiczne, 45, 267-292.

Rutkowska, K. (2004). Lituanizmy leksykalne w gwarach polskich na obszarze ignalińsko-jezioroskim. Prace Filologiczne, 49, 427-436.

Rutkowska, K. (2013). Wpływy litewskie i wschodniosłowiańskie na obszarze ignalińskim na Litwie. Prace Filologiczne, 59, 524-541. 
Turska, H. (1982). O powstaniu polskich obszarów językowych na Wileńszczyźnie. W J. Rieger \& W. Werenicz (Red.), Studia nad polszczyzną kresowa (T. 1, ss. 19-122). Wrocław: Zakład Narodowy im. Ossolińskich. (Przedruk z r. 1939)

Ананьева, Н. В. (1974). Морфологические чередования в польском говоре деревни Гайде Игналинского района Литовской ССР. Вестник Московского Государственного Университета (серия 10: Филология), 50-58.

Ананьева, Н. В. (1982). Чередования в парадигме настоящего времени глаголов польского говора деревни Гайде Игналинского района Литовской ССР. W J. Rieger \& W. Werenicz (Red.), Studia nad polszczyzną kresowa (T. 1, ss. 179-193). Wrocław: Zakład Narodowy im. Ossolińskich.

Ананьева, Н. В. (1983). Некоторые особенности фонетической интерференции у полилингвов одного периферийного польского говора. W J. Rieger \& W. Werenicz (Red.), Studia nad polszczyzną kresową (T. 2, ss. 65-72). Wrocław: Zakład Narodowy im. Ossolińskich.

\section{Bibliography}

Anan'eva, N. V. (1974). Morfologicheskie cheredovaniia v pol'skom govore derevni Gaĭde Ignalinskogo ră̌na Litovskoŭ SSR. Vestnik Moskovskogo Gosudarstvennogo Universiteta (series 10: Filologiia), 50-58.

Anan'eva, N. V. (1982). Cheredovaniia v paradigme nastoiashchego vremeni glagolov pol'skogo govora derevni Gaĭde Ignalinskogo ră̌ona Litovskoŭ SSR. In J. Rieger \& W. Werenicz (Eds.), Studia nad polszczyzna kresowa (Vol. 1, pp. 179-193). Wrocław: Zakład Narodowy im. Ossolińskich.

Anan'eva, N. V. (1983). Nekotorye osobennosti foneticheskoŭ interferentsii u polilingvov odnogo periferiünogo pol'skogo govora. In J. Rieger \& W. Werenicz (Eds.), Studia nad polszczyzna kresowa (Vol. 2, pp. 65-72). Wrocław: Zakład Narodowy im. Ossolińskich.

Karaś, H. (2001). O sytuacji języka polskiego na obszarze smołwieńskim na Litwie. Prace Filologiczne, 45, 267-292.

Rutkowska, K. (2004). Lituanizmy leksykalne w gwarach polskich na obszarze ignalińsko-jezioroskim. Prace Filologiczne, 49, 427-436.

Rutkowska, K. (2013). Wpływy litewskie i wschodniosłowiańskie na obszarze ignalińskim na Litwie. Prace Filologiczne, 59, 524-541.

Turska, H. (1982). O powstaniu polskich obszarów językowych na Wileńszczyźnie. In J. Rieger \& W. Werenicz (Eds.), Studia nad polszczyzna kresowa (Vol. 1, pp. 19-122). Wrocław: Zakład Narodowy im. Ossolińskich. (Reprint, 1939) 


\title{
O języku, dawnych czasach i obrzędach w okolicach Mejkszt na Litwie
}

\section{Streszczenie}

W publikacji przedstawione są teksty nagrane w lipcu 2000 r. podczas badań terenowych na obszarze smołwieńskim polszczyzny północnokresowej. Pochodzą one od informatorki ze wsi Mejkszty (lit. Meikštai). Wieś jest położona w rejonie ignalińskim (lit. Ignalinos rajonas), na samej granicy z Białorusią. Teren ten charakteryzuje się historycznie ukształtowaną wielojęzycznością, gdzie sąsiadują ze sobą wsie litewskie, polskie i staroobrzędowców. Częste są też kontakty miejscowych mieszkańców z rodziną lub znajomymi, mieszkającymi na Białorusi. Mieszkańcy tych miejscowości znają cztery języki: polski, litewski, rosyjski i gwarę białoruską. W zachowanych wsiach polskich kodem podstawowym pozostaje dotychczas polszczyzna, której używa się we wszystkich trzech pokoleniach jako języka domowego, natomiast w kontaktach zewnętrznych mogą być używane pozostałe odmiany językowe.

Badania miały na celu nie tylko odnotowanie języka używanego w tych miejscowości, lecz też udokumentowanie bardzo zróżnicowanej warstwy kulturowej, dlatego też nagrywano opowieści o obrzędach, zwyczajach, a także pieśni ludowe. W trakcie badań stosowano różnorodne kwestionariusze - językowe, socjolingwistyczne i etnolingwistyczne. Przedstawiony tekst składa się z opowiadań o charakterze historycznym i etnograficznym. W zapisie półfonetycznym zachowano podstawowe cechy języka informatorki, który reprezentuje odmianę smołwieńską polszczyzny na Litwie.

Słowa kluczowe: Smołwy; język polski na Litwie; narracje historyczne; podania ludowe

\section{The language, history and ceremonies in the area of Meikštai in Lithuania}

\begin{abstract}
This publication is a report of the field studies carried out in July 2000 in the Smalvos area in Lithuania. This area is characterized by historically shaped multilingualism, where Lithuanian, Polish and Russian Old Believers' villages are adjacent. Also frequent are contacts between local residents with family or friends who live in Belarus. As a result, the inhabitants of these villages are familiar with four languages: Polish, Lithuanian, Russian, and Belarusian dialect. The Polish villages preserved the basic Polish language which is used by all three generations as a home language, while in the external contacts other language varieties can be used.
\end{abstract}


The ongoing research was not only aimed at examination of the language of these areas but also at documentation of very diverse cultural layers, therefore rites, customs and folk songs were recorded. Many different questionnaires were used in the study - linguistic, ethno-linguistic and social-linguistic. The source text in the book consists of stories kept in historical and ethnographic character, basic features of the informer, who represents a Smalvos variety of the Polish language in Lithuania, have been preserved in the phonetic record.

Keywords: Smalvos; Polish in Lithuania; historical narratives; folklore

Correspondence: K. Rutkowska, Vilnius University, e-mail: kristina.rutkovska@gmail.com The study was conducted at author's own expense.

Competing interests: the author is a member of the Scientific Board of this journal. 